\title{
KEPRIBADIAN DAN KEADILAN ORGANISASI TERHADAP ORGANIZATIONAL CITIZENSHIP BEHAVIOR
}

\section{PERSONALITY AND ORGANIZATIONAL JUSTICE TOWARDS ORGANIZATIONAL CITIZENSHIP BEHAVIOR}

\author{
W Firmansyah1a \\ 1 Program Studi Manajemen Pendidikan Islam, Fakultas Keguruan dan Ilmu Pendidikan, \\ Universitas Djuanda Bogor, Jl. Tol Ciawi No. 1 Kotak Pos 35 Ciawi Bogor 16720 \\ a Korespondensi: Wilis Firmansyah, Email: wilisfirmansyah@yahoo.com \\ (Diterima: 12-02-2019; Ditelaah: 15-02-2019; Disetujui: 25-03-2019)
}

\begin{abstract}
This study aims to examine (1) the effect of personality towards organizational citizenship behavior, (2) the effect of organizational justice towards organizational citizenship behavior, (3) the effect of personality towards organizational justice. This research used quantitative approach. The research was conducted to all of teacher of Junior High School, by using a survey method with path analysis applied in testing hypothesis. Sample in this research were 91 teacher of Junior High School as respondents. The research instruments were a questionnaire and documentation. The data analysis technique was path analisis. The conclusions of this research are: (1) there is direct positive effect of personality towards organizational citizenship behavior indicated by a path coefficient of 0,294, coefficient tobserved $=2,882$, and significance value of 2,63 (2) there is direct positive effect of organizational justice towards organizational citizenship behavior indicated by a path coefficient of 0,294 , coefficient tobserved $=2,882$, and significance value of 2,63 and (3) there is direct positive effect of personality towards organizational justice. indicated by a path coefficient of 0,294, coefficient tobserved $=2,882$, and significance value of 2,63.
\end{abstract}

Keywords: organizational justice, organizational citizenship behavior, personality.

\begin{abstract}
ABSTRAK
Tujuan dari penelitian ini adalah untuk menguji (1) pengaruh kepribadian terhadap organizational citizenship behavior, (2) pengaruh keadilan organisasi terhadap organizational citizenship behavior, (3) pengaruh kepribadian tehadap keadilan organisasi. Penelitian ini menggunakan pendekatan kuantitatif. Metode penelitian yang digunakan adalah metode survei dengan analisis jalur di Sekolah Menengah Pertama. Sampel penelitian sebanyak 91 orang guru Sekolah Menengah Pertama yang menjadi responden. Instrumen penelitian ini menggunakan kuesioner dan dokumentasi. Teknik analisis data dalam penelitian ini menggunakan analisis jalur. Hasil penelitian menunjukkan bahwa (1) terdapat pengaruh positif kepribadian terhadap organizational citizenship behavior dengan nilai koefisien jalur sebesar 0,294, nilai $t_{\text {hitung }}$ sebesar 2,882 dan nilai signifikansi 2,63 (2) terdapat pengaruh positif keadilan organisasi terhadap organizational citizenship behavior dengan nilai koefisien jalur sebesar 0,246, nilai thitung sebesar 2,416, dan nilai signifikansi 1,99 (3) pengaruh kepribadian tehadap keadilan organisasi dengan nilai koefisien jalur sebesar 0,347, nilai thitung sebesar 3,407 dan nilai signifikansi 2,63.

Kata kunci: kepribadian, keadilan organisasi, organizational citizenship behavior.
\end{abstract}


Firmansyah, W. (2019). Pengaruh Kepribadian dan Keadilan Organisasi Terhadap Organizational Citizenship Behavior. Tadbir Muwahhid, 3(1), 53-67.

\section{PENDAHULUAN}

Era globalisasi merupakan era yang menandakan adanya persaingan di setiap sektor, sehingga semua pihak diberbagai bidang dan sektor pembangunan tak terkecuali bidang pendidikan dituntut untuk selalui memperhatikan aspek kompetensinya. Hal ini jelas menunjukkan bahwa betapa pentingnya pendidikan sehingga harus selalu diperhatikan dan ditingkatkan tak hanya kuantitas saja melainkan kualitas juga yang seharusnya dilakukan secara berkesinambungan, dengan demikian pendidikan mampu dimanfaatkan sebagai sarana untuk menciptakan sumber daya manusia yang unggul.

Dalam pembangunan nasional, pendidikan menjadi sesuatu yang penting karena dapat membentuk pribadi bangsa Indonesia yang cerdas sekaligus juga menjadi motor penggerak dalam menciptakan generansi Indonesia yang seutuhnya dan unggul. Peran sumber daya manusia yang berkualitas dapat menentukan salah atu keberhasilahan pembangunan nasional, tak hanya bagi penentu keijakan, pengambilan keputusan melainkan juga kepada pelaksana teknis dan pelaksana pengawasan pembangunan. Kualitas sumber daya manusia ini adalah bagian dari hasil sebuah pembangunan nasional bidang pendidikan yang mempunyai peran sentral bagi peningkatan pembangunan nasional.

Menurut (Nugroho, 2009) pendidikan untuk memiliki pekerjaan bukan melahirkan robot-robot sebagai suatu bagian dari mesin raksasa dalam suatu industri tetapi manusia-manusia bebas yang kreatif agar dapat melahirkan berbagai perubahan yang diinginkan. Kegiatan pada bidang pendidikan dapat menyalurkan potensi bagi siswa yang dimiliki dalam dirinya yang mampu dikembangkan sesuai dengan bakat serta kemampuan yang dimilikinya..

Peran bidang pendidikan penting sekali untuk menciptakan kualitas manusia sebuah negara. Melalui proses transformasi nilainilai budaya pada bidang pendidikan yang turun temurun bagi masyarakat sehingga hasil akhir transformasi budaya ini diharapkan mampu membentuk karakter bangsa. Pemerintah Indonesia sangat memahami pentingnya pendidikan bagi pembangunan nasional sehingga selalu mendukung rencana kegiatan maupun program yang memposisikan kegiatan pendidikan sebagai kegiatan sangat berperan penting bagi pembangunan nasional. Pendidikan bagi pemerintah Indonesia selain dapat membentuk kualitas dan harkat yang baik bagi manusia tetapi juga sebagai indikator kemajuan martabat suatu bangsa.

Guru berperan tidak hanya sebagai bagian aspek yang penting bagi pendidikan namun guru juga menjadi bagian penyebab mengapa pendidikan masih tertinggal dan tentu perlu perbaikan secara terusmenerus. Kelemahan ini menjadi kekhawatiran karena bisa saja akan diikuti juga dengan kelemahan para siswa. Oleh sebab itu kinerja dan kemampuan guru harus terus ditingkatkan melalui pelatihanpelatihan. Faktor lain penyebab pendidikan yang masih perlu perbaikan adalah rendahnya pembinaan karakter siswa oleh guru di sekolah. Aksi penyimpangan pada pelajar seperti tawuran merupakan bentuk 
kurangnya perhatian guru terhadap siswanya diluar tugas utamanya dalam mengajar. Selain itu, adanya temuan bahwa pelaksanaan Ujian Nasional di sekolah terindikasi adanya kecurangan yang melibatkan peran guru di sekolah.

Kenyataan tersebut selain megindikasikan peyebab ketertinggalan pendidikan juga mengindikasi bahwa guru selama ini hanya berusaha untuk mengerjakan tugas-tugas formal mereka (intra-role), dan kurang dalam melakukan tugas-tugas di luar tanggung jawabnya (ekstra-role). Perilaku ekstra-role atau organizational citizenship behavior (OCB) bagi organisasi sangat diperlukan seperti sekolah karena dapat meningkatkan kemajuan sebuah organisasi.

Menurut (Schermerhorn., 2012) bahwa Organizational Citizenship Behavior merupakan suatu yang orang-orang lakukan untuk bekerja ekstra dalam pekerjaan mereka. Sedangkan (Stephen P. Robbins, 2007) menjelaskan OCB sebagai perilaku sukarela yang bukan bagian dari persyaratan kerja formal karyawan, namun yang mendorong fungsi efektif organisasi. Berdasarkan pernyataan para ahli yang dikemukakan di atas Organizational Citizenship Behavior mempunyai arti sebagai perilaku yang melampaui tugas formal yang dilakukan secara sukarela dan berkontribusi positif serta mendorong efektifitas organisasi, dengan indikator: membantu kepentingan orang lain, kesadaran untuk bekerja melebihi tugas, berpartisipasi demi kepentingan organisasi, bersikap sportif dalam bekerja, sopan dalam bekerja.

Dalam penelitian tentang perilaku organisasi, OCB mempunyai pengaruh yang disebabkan oleh beberapa faktor atau penyebab, antara lain adalah kepribadian dan keadilan organisasi. Menurut
(M.Ryckman, 2008) kepribadian merupakan organisasi dinamik yang dimiliki seseorang, yang secara unik mempengaruhi kognitif, motivasi, dan perilaku dalam berbagai situasi. Sedangkan (Jason A. Colquit, 2011) mengungkapkan kepribadian sebagai, acuan terstruktur dan kecenderungan seseorang untuk menjelaskan pola-pola sifat yang mempunyai pengaruh dengan pikiran, emosional dan tingkah laku. Kepribadian juga menjadi faktor penentu mengapa seseorang berperilaku seperti yang mereka kerjakan dan mengapa seseorang mempunyai perilaku yang bermanfaat maupun tidak bermanfaat untuk organisasi.

Sikap dan tindakan seseorang akan sangat ditetukan oleh kepribadiannya. Oleh karena itu, jika ingin mendalami sikap dan tindakan seseorang dalam organisasi, maka akan sangat membantu jika mengetahui kepribadian orang tersebut. Jika kepala sekolah dapat memahami perilaku setiap gurunya dengan baik maka kepala sekolah tersebut akan mudah mengatur sebuah organisasi sekolah. Kepala sekolah dengan mudah berkomunikasi dengan setiap guru. Memahami karakteristik setiap guru melalui pendekatan yang baik dan bijaksana. Sehingga tujuan Sekolah akan mudah tercipta karena adanya interaksi yang baik antara kepala sekolah dan setiap guru.

Adapun keadilan organisasi mampu mempunyai peran sebagai sumber yang menjadi perantara bagi setiap orang agar terciptanya semnagat dalam bekerja. Keadailan organisasi akan tercipta jika sebuah intansi atau lembaga mampu bersikap penuh perhatian dan adil bagi karyawanannya. Menurut Robbins dan Judge (2008:186) keadilan organisasi adalah seluruh persepsi tentang keadilan di tempat kerja yang dibangun dari keadilan distributif, prosedural dan interaksional. Keadilan tidak hanya berlaku dalam 
komunitas masyarakat, tetapi juga berlaku dalam organisasi.

Dalam sebuah lembaga setiap anggota diharuskan memberikan dan menunjukkan kinerja yang baik. Keadilan organisasi berperan sebagai sumber yang memberikan semangat kerja seseorang, dengan demikian perusahaan hendaknya berlaku adil bagi setiap karyawannya. Keadilan bukan hanya untuk masyarakat, tetapi juga bagi organisasi.

Uraian tersebut menjelaskan perilaku OCB sangat penting untuk organisasi, terutama untuk mendorong dan mengangkat organisasi sekolah sebagai pusat pembelajaran yang benar-benar mampu menghasilkan pendidikan yang berkualitas unggul. Akan tetapi kenyataannya menunjukkan bahwa guru belum memahami arti pentingnya dari OCB. Lebih lanjut, mereka juga belum menyadari adanya pengaruh kepribadian dan keadilan organisasi terhadap OCB.

\section{METODE}

\section{Jenis Penelitian}

Jenis penelitian ini memakai pendekatan penelitian kuantitatif yang menjelaskan penelitian untuk mencari solusi dari permasalahan yang diteliti dengan teknik pengukuran yang tepat terhadap variabelvariabel tertentu, sehingga menghasilkan kesimpulan yang dapat digeneralisasikan. Penelitian kuantitatif juga melakukan pencatatan hasil penelitian dalam bentuk angka-angka dan analisis menggunakan statistik. Selain itu penelitian kuantitatif digunakan untuk meneliti permasalahan yang sudah jelas, data dapat diamati dan dapat diukur, peneliti bermaksud untuk menguji hipotesis dan generalisasi.
Adapun tujuan dalam penelitian ini adalah mengetahui adanya pengaruh kepribadian dan keadilan organisasi terhadap Organizational Citizenship Behavior. Penelitian ini menggunakan analisis jalur sebagai alat analisisnya. Peranan statistik sangat menentukan dalam penyusunan penelitian ini. Untuk melihat pengaruh antara variabel eksogen dan endogen dirancang konstelasi variabel sebagai berikut:

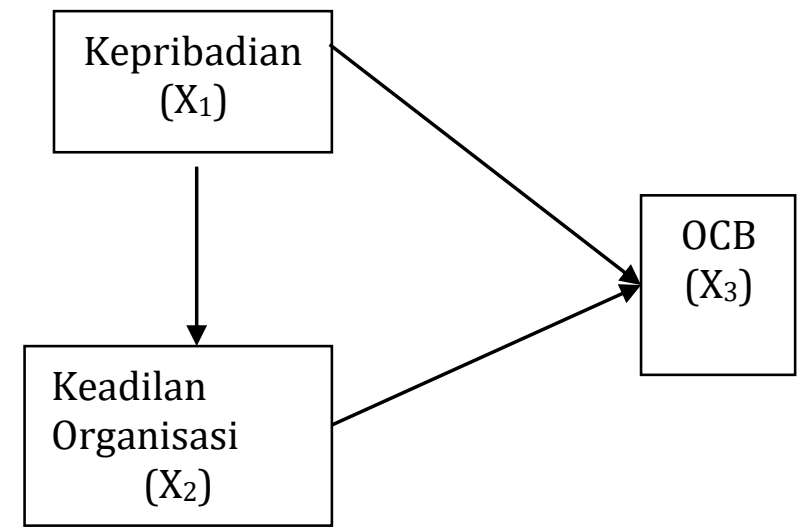

Gambar 1 Desain penelitian

Keterangan: X1= Kepribadian (variabel eksogen); $\mathrm{X} 2=$ Keadilan organisasi (variabel eksogen); X3= Organizational Citizenship Behavior (variabel endogen).

\section{Waktu dan Tempat Penelitian}

Penelitian ini dilaksanakan pada Sekolah Menengah Pertama (SMP) Swasta di Wilayah Kecamatan Jagakarsa Jakarta Selatan. Waktu kegiatan dalam penelitian ini dilakukan kurang lebih 6 bulan. Dalam kurun waktu tersebut peneliti membagi penelitian ini ke dalam beberapa tahapan. Yaitu tahap persiapan, tahap pengumpulan data, tahap pengolahan dan analisis data serta tahap penulisan laporan.

\section{Populasi dan Sampel}

Populasi mempunyai sebuah makna sebagai wilayah generalisasi berupa subjek atau objek yang memiliki kualitas dan karakteritik tertentu yang ditetapkan oleh peneliti untuk dipelajari dan kemudian 
ditarik kesimpulan. Adapun populasi penelitian ini adalah guru-guru SMP Swasta di Wilayah Jakarta Selatan yang berjumlah 118 orang.

Sampel dapat diartikan sebagian dari populasi yang diteliti. Mengingat demikian luasnya wilayah penelitian, maka pelaksanaan penelitian dilakukan dengan meneliti sampel yang dianggap mampu mewakili karakteristik dan sifat-sifat yang ada dalam populasi. Sampel dalam penelitian ini diambil dengan menggunakan teknik Simple Random Sampling atau pengambilan sampel secara acak sederhana. Sampel dalam penelitian ini berjumlah 91 guru.

\section{Teknik Pengumpulan Data}

Teknik pengumpulan data dapat diartikan sebagai sebuah cara untuk mengumpulkan informasi yang dibutuhkan bagi peneliti dari responden sesuai lingkup yang sedang diteliti. Teknik pengumpulan data yang digunakan peneliti adalah dengan menggunakan kuesioner skala penilaian.

\section{Uji Coba Instrumen}

Instrumen diuji terlebih dahulu sebelum dipergunakan dalam penelitian. pengujian instrument tersebut meliputi uji validitas dan uji reliabilitas. Adapun hasil uji coba instrument yang telah dilakukan peneliti diperoleh butir-butir instrument yang valid dan tidak valid. Instrumen yang tidak valid dihilangkan atau tidak dipergunakan dalam penelitian.

\section{Variabel OCB}

Data variabel OCB diperoleh melalui angket yang diberikan kepada guru, kemudian oleh peneliti disusun atas dasar teori yang relevan. Instrumen dalam penelitian ini dikembangkan dalam bentuk pertanyaan atau pernyataan berupa positif. Untuk mengukur OCB terdiri dari 30 butir pertanyaan dengan lima alternatif jawaban yaitu Sangat Sering $=5$, Sering $=4$, Kadang = 3 , Jarang $=2$, Tidak Pernah $=1$ sesuai dengan tabel 1

Tabel 1 Kisi-kisi variabel organizational citizenship behavior

\begin{tabular}{|c|c|c|c|c|}
\hline No & Indikator & $\begin{array}{c}\text { Nomor Butir } \\
\text { Sebelum Uji Coba }\end{array}$ & $\begin{array}{c}\text { Nomor Butir } \\
\text { Sesudah Uji Coba }\end{array}$ & $\begin{array}{l}\text { Nomor } \\
\text { Gugur }\end{array}$ \\
\hline 1 & $\begin{array}{l}\text { Membantu kepentingan orang } \\
\text { lain }\end{array}$ & $1,2,3,4,5,6$ & $1,2,4,5,6$ & 3 \\
\hline 2 & $\begin{array}{l}\text { Kesadaran untuk bekerja } \\
\text { melebihi tugas }\end{array}$ & $\begin{array}{r}7,8,9,10,11,12,13 \\
14\end{array}$ & $\begin{array}{r}7,8,9,10,12,13 \\
14\end{array}$ & 11 \\
\hline 3 & $\begin{array}{ll}\text { Berpartisipasi } & \text { demi } \\
\text { kepentingan organisasi } & \end{array}$ & $15,16,17,18,19$ & $15,16,17,18,19$ & - \\
\hline 4 & Bersikap sportif dalam bekerja & $20,21,22,23,24,25$ & $20,22,23,24,25$ & 22 \\
\hline 5 & Sopan dalam bekerja & $26,27,28,29,30$ & $26,27,28,29,30$ & - \\
\hline \multicolumn{2}{|c|}{ Jumlah Pernyataan } & 30 & 27 & 3 \\
\hline
\end{tabular}

Berdasarkan Uji validitas menggunakan koefisien korelasi bahwa Organizational Citizenship Behavior dari 30 butir pernyataan terdapat 3 butir yang tidak valid (drop), yaitu butir nomor 3, 11 dan 22 . Jumlah butir yang valid akan digunakan sebagai alat pengambilan data penelitian sebanyak 27 butir. Sedangkan Uji Reliabel 
dengan teknik Alpha Cronbach diketahui OCB dengan koefisien reliabilitas sebesar 0.960 .

\section{Kepribadian}

Data kepribadian diperoleh melalui penyebaran angket kepada guru, disusun oleh peneliti berdasarkan teori yang relevan. Instrumen dalam penelitian ini dikembangkan dalam bentuk pertanyaan atau pernyataan berupa positif. Untuk mengukur kepribadian terdiri dari 30 butir pertanyaan dengan lima alternatif jawaban yaitu Sangat Sering $=5$, Sering $=4$, Kadang = 3 , Jarang $=2$, Tidak Pernah $=1$ sesuai dengan

Tabel 2 Kisi-kisi variabel kepribadian

\begin{tabular}{llrrr}
\hline No & \multicolumn{1}{c}{ Indikator } & $\begin{array}{r}\text { Nomor Butir Sebelum } \\
\text { Uji Coba }\end{array}$ & $\begin{array}{r}\text { Nomor Butir Sesudah } \\
\text { Uji Coba }\end{array}$ & $\begin{array}{r}\text { Nomor } \\
\text { Gugur }\end{array}$ \\
\hline 1 & Ekstraversi & $1,2,3,4,6,7$ & $1,2,3,4,6,7$ & - \\
2 & Keramahtamahan & $8,9,10,11,12,13,14$ & $8,10,11,12,13,14$ & 9 \\
3 & Kesadaran & $15,16,17,18,19,20$ & $15,17,18,19,20$ & 16 \\
4 & Stabilitas emosional & $21,22,23,24,25$ & $21,22,23,24,25$ & - \\
5 & $\begin{array}{l}\text { Keterbukaan terhadap } \\
\text { pengalaman }\end{array}$ & $26,27,28,29,30$ & $26,27,28,29,30$ & - \\
Jumlah Pernyataan & 30 & & 28 & 2 \\
\hline
\end{tabular}

Berdasarkan hasil perhitungan validitas Kepribadian diketahui dari 30 butir pernyataan terdapat 2 butir yang tidak valid (drop), yaitu butir nomor 9 dan 16. Jumlah butir yang valid akan digunakan sebagai alat pengambilan data penelitian sebanyak 28 butir. Dari perhitungan dengan teknik Alpha Cronbach diketahui hasil perhitungan reliabilitas instrumen variabel Kepribadian sangat tinggi dengan koefisien reliabilitas sebesar 0.941 .

\section{Keadilan Organisasi}

Data keadilan organisasi diperoleh melalui penyebaran angket kepada guru, disusun oleh peneliti berdasarkan teori yang relevan. Instrumen dalam penelitian ini dikembangkan dalam bentuk pertanyaan atau pernyataan berupa positif. Untuk mengukur keadilan terdiri dari 30 butir pertanyaan dengan lima alternatif jawaban yaitu Sangat Setuju $=5$, Setuju $=4$, Netral= 3, Tidak Setuju $=2$, Sangat Tidk Setuju $=1$ sesuai dengan tabel 3

Tabel 3 Kisi-kisi variabel keadilan organisasi

\begin{tabular}{llrrr}
\hline No & \multicolumn{1}{c}{ Indikator } & $\begin{array}{r}\text { Nomor Butir } \\
\text { Sebelum Uji Coba }\end{array}$ & $\begin{array}{c}\text { Nomor Butir } \\
\text { Sesudah Uji Coba }\end{array}$ & $\begin{array}{r}\text { Nomor } \\
\text { Gugur }\end{array}$ \\
\hline 1 & Kesetaraan & $1,2,3,4$ & $1,2,3,4$ & - \\
2 & Kebutuhan & $5,6,7$ & 5,7 & 6 \\
3 & $\begin{array}{l}\text { Penghargaan atas inspirasi dalam } \\
\text { pengambilan keputusan }\end{array}$ & $8,9,10$ & $8,9,10$ & - \\
4 & Konsistensi & $11,12,13,14$ & $11,13,14$ & 12 \\
5 & Perlakuan yang santun dari & $15,16,17,18,19$ & $15,16,17,18,19$ & - \\
\hline
\end{tabular}




\begin{tabular}{llrrr}
\hline \multicolumn{2}{l}{ atasan } & & & \\
6 & $\begin{array}{l}\text { Penghormatan atas harga diri } \\
\text { dan martabatnya }\end{array}$ & $20,21,22$ & $20,21,22$ & - \\
7 & $\begin{array}{l}\text { Penjelasan prosedur yang } \\
\text { sesungguhnya } \\
\text { Penyampaian informasi yang } \\
\text { bijak }\end{array}$ & $23,24,25$ & $23,24,25$ & - \\
Jumlah Pernyataan & 30 & $26,27,28,29,30$ & 28 \\
\hline
\end{tabular}

Berdasarkan hasil perhitungan validitas Keadilan Organisasi diketahui dari 30 butir pernyataan terdapat 2 butir yang tidak valid (drop), yaitu butir nomor 6 dan 12. Jumlah butir yang valid akan digunakan sebagai alat pengambilan data penelitian sebanyak 28 butir. Dari perhitungan dengan teknik Alpha Cronbach diketahui hasil perhitungan reliabilitas instrumen variabel Keadilan Organisasi sangat tinggi dengan koefisien reliabilitas sebesar 0.961 .

\section{Teknik Analisis Data}

Teknik analisis data yang dipakai adalah analisis data secara deskriptif dan inferensial. Penggunaan teknik analisis data secara deskriptif untuk mendapatkan gambaran karakteristik penyebaran nilai setiap variabel yang diteliti.

Analisis deskriptif digunakan dalam hal penyajian data, ukuran sentral, dan ukuran penyebaran. Penyajian data menggunakan daftar distribusi dan histogram. Ukuran sentral meliputi mean, median, dan modus. Ukuran penyebaran meliputi varians dan simpangan baku.

Sedangkan analisis inferensial menggunakan analisis jalur untuk menguji hipotesis. Alpha Pengujian hipotesis yang digunakan peneliti adalah $\alpha=0,05$. Peneliti terlebih dahulu melakukan uji normalitas menggunakan teknik Lilliefors.

Untuk menghitung pengaruh langsung dan tak langsung dari variable bebas terhadap suatu variable terikat, tercermin dari koefisien jalur. Sedangkan untuk menentukan koefisien jalur diperlukan persyaratan sebagai berikut: (1) hubungan antara tiap dua variable harus merupakan hubungan yang linier, aditif, dan kausal; (2) sistem menganut prinsip eka arah: (3) semua variabel residu tidak saling berkorelasi dan juga tidak berkorelasi dengan variabel penyebab; serta (4) data masing-masing variabel adalah kontinum.

\section{Hipotesis Statistik}

Hipotesis pertama

$\mathrm{H}_{\mathrm{o}}: \beta_{31} \leq 0$

$\mathrm{H}_{1}: \beta_{31}>0$

Hipotesis kedua

Ho : $\beta_{32} \leq 0$

$\mathrm{H} 1: \beta_{32}>0$

Hipotesis ketiga

Ho : $\beta_{21} \leq 0$

$\mathrm{H} 1: \beta_{21}>0$

Keterangan: $\mathrm{H}_{0}=$ Hipotesis nol (nihil); $\mathrm{H}_{1}=$ Hipotesis alternatif; $\beta_{21}=$ Koefisien Jalur tentang pengaruh langsung kepribadian $\left(\mathrm{X}_{1}\right)$ terhadap keadilan organisasi $\left(X_{2}\right) ; \beta_{32}=$ Koefisien Jalur tentang pengaruh Iangsung keadilan organisasi $\left(\mathrm{X}_{2}\right)$ terhadap organizational citizenship behavior $\left(\mathrm{X}_{3}\right) ; \beta_{31}=$ Koefisien Jalur tentang pengaruh Iangsung kepribadian $\left(\mathrm{X}_{1}\right)$ terhadap organizational citizenship behavior $\left(\mathrm{X}_{3}\right)$. 


\section{HASIL DAN PEMBAHASAN}

\section{Hasil}

\section{Data Deskriptif}

Berdasarkan analisi keseluruhan data pada deskriptif data sudah dapat diketahui. Deskripsi data pada bagian ini meliputi data variabel $\mathrm{X}_{3}$ OCB sebagai variabel terikat (endogenous), variabel $\mathrm{X}_{1}$ (Kepribadian) dan variabel $\mathrm{X}_{2}$ (Keadilan Organisasi) sebagai variabel bebas (exsogenous). Deskripsi masing-masing variabel disajikan secara berturut-turut mulai dari variabel $\mathrm{X}_{3}, \mathrm{X}_{1}$, dan $\mathrm{X}_{2}$.

\section{Variabel OCB}

Distribusi Frekuensi Variabel Organizational Behavior Organizational (OCB) dapat dilihat pada tabel 4

Tabel 4 Distribusi frekuensi skor variabel OCB

\begin{tabular}{|c|c|c|c|c|c|c|c|}
\hline \multirow{2}{*}{ No } & \multirow{2}{*}{\multicolumn{2}{|c|}{ Kelas Interval }} & \multicolumn{2}{|c|}{ Batas } & \multicolumn{3}{|c|}{ Frekuensi } \\
\hline & & & Bawah & Atas & Absolut & Komulatif & Relatif \\
\hline 1 & 92 & 97 & 91,5 & 97,5 & 7 & 7 & $7,69 \%$ \\
\hline 2 & 98 & 103 & 97,5 & 103,5 & 8 & 15 & $8,79 \%$ \\
\hline 3 & 104 & 109 & 103,5 & 109,5 & 18 & 33 & $19,78 \%$ \\
\hline 4 & 110 & 115 & 109,5 & 115,5 & 23 & 56 & $25,27 \%$ \\
\hline 5 & 116 & 121 & 115,5 & 121,5 & 17 & 73 & $18,68 \%$ \\
\hline 6 & 122 & 127 & 121,5 & 127,5 & 15 & 88 & $16,48 \%$ \\
\hline \multirow[t]{2}{*}{7} & 128 & 133 & 127,5 & 133,5 & 3 & 91 & $3,30 \%$ \\
\hline & & & & & 91 & & $100 \%$ \\
\hline
\end{tabular}

Dari data yang diperoleh di lapangan yang kemudian diolah secara statistik ke dalam daftar distribusi frekuensi, banyaknya kelas yang dihitung menurut aturan Sturges, diperoleh tujuh kelas dengan nilai skor maksimum 131 dan skor minimum 92, sehingga rentang skor sebesar 39. Berdasarkan hasil perhitungan statistik deskriptif diperoleh bahwa instrument OCB mempunyai nilai rata-rata sebesar 112,46

Tabel 5 Distribusi frekuensi skor variabel kepribadian

\begin{tabular}{lrrrrrrrr}
\hline \multirow{2}{*}{ No } & \multirow{2}{*}{ Kelas Interval } & \multicolumn{2}{c}{ Batas } & \multicolumn{3}{c}{ Frekuensi } \\
\cline { 4 - 9 } & & & \multicolumn{1}{c}{ Bawah } & Atas & \multicolumn{1}{c}{ Absolut } & \multicolumn{1}{l}{ Komulatif } & \multicolumn{1}{c}{ Relatif } \\
\hline 1 & 100 & - & 105 & 99,5 & 105,5 & 7 & 7 & $7,69 \%$ \\
2 & 106 & - & 111 & 105,5 & 111,5 & 9 & 16 & $9,89 \%$ \\
3 & 112 & - & 117 & 111,5 & 117,5 & 35 & 51 & $38,46 \%$ \\
4 & 118 & - & 123 & 117,5 & 123,5 & 21 & 72 & $23,08 \%$ \\
\hline
\end{tabular}

dengan nilai standar deviasi 9,36 dimana nilai variansnya sebesar 87,5624 nilai median 112,76 dan nilai modus sebesar $112,23$.

\section{Variabel Kepribadian}

\section{Distribusi Frekuensi variabel kepribadian dapat dilihat pada tabel 5}




\begin{tabular}{rrrrrrrrr}
\hline 5 & 124 & - & 129 & 123,5 & 129,5 & 11 & 83 & $12,09 \%$ \\
6 & 130 & - & 135 & 129,5 & 135,5 & 5 & 88 & $5,49 \%$ \\
7 & 136 & - & 141 & 135,5 & 141,5 & 3 & 91 & $3,30 \%$ \\
& & & & & & 91 & & $100 \%$ \\
\hline
\end{tabular}

Data kepribadian mempunyai rentang skor teoretik antara 28 sampai 140 dan rentang skor empiris antara 100 sampai dengan 140, sehingga rentang skor sebesar 40. Hasil perhitungan data diperoleh rata-rata sebesar 117,58; simpangan baku sebesar
8,31; varians sebesar 69,1126; median sebesar 116,56; dan modus sebesar 115,40.

Variabel Keadilan Organisasi

Distribusi Frekuensi Variabel keadilan organisasi dapat dilihat pada tabel 6

Tabel 6 Distribusi frekuensi skor variabel keadilan organisasi

\begin{tabular}{|c|c|c|c|c|c|c|c|}
\hline \multirow{2}{*}{ No } & \multirow{2}{*}{\multicolumn{2}{|c|}{ Kelas Interval }} & \multicolumn{2}{|c|}{ Batas } & \multicolumn{3}{|c|}{ Frekuensi } \\
\hline & & & Bawah & Atas & Absolut & Komulatif & Relatif \\
\hline 1 & 103 & 108 & 102,5 & 108,5 & 8 & 8 & $8,79 \%$ \\
\hline 2 & 109 & 114 & 108,5 & 114,5 & 18 & 26 & $19,78 \%$ \\
\hline 3 & 115 & 120 & 114,5 & 120,5 & 21 & 47 & $23,08 \%$ \\
\hline 4 & 121 & 126 & 120,5 & 126,5 & 8 & 55 & $8,79 \%$ \\
\hline 5 & 127 & 132 & 126,5 & 132,5 & 11 & 66 & $12,09 \%$ \\
\hline 6 & 133 & - 138 & 132,5 & 138,5 & 23 & 89 & $25,27 \%$ \\
\hline \multirow[t]{2}{*}{7} & 139 & 144 & 138,5 & 144,5 & 2 & 91 & $2,20 \%$ \\
\hline & & & & & 91 & & $100 \%$ \\
\hline
\end{tabular}

Data keadilan organisasi mempunyai rentang skor teoretik antara 28 sampai 140 , dan rentang skor empiris antara 103 sampai dengan 140, sehingga rentang skor sebesar 37. Hasil perhitungan data diperoleh ratarata sebesar 122,42; simpangan baku sebesar 10,95; varians sebesar 119,8237; median sebesar 120,07; dan modus sebesar 134,68 .

\section{Uji Prasyarat Analisis Data}

\section{Uji Normalitas}

Uji normalitas dalam penelitian ini menggunakan teknik uji Liliefors. Adapun kriteria uji normalitas adalah sebagai berikut :

Ho : Data berdistribusi normal, jika nilai Lhitung $\leq$ nilai $\mathrm{L}_{\text {tabel }}$

Hi : Data tidak berdistribusi normal, jika nilai $L_{\text {hitung }}>$ nilai $L_{\text {tabel }}$ Sesuai dengan tabel 7

Tabel 7 Hasil pengujian normalitas galat taksiran regresi

\begin{tabular}{lllrrl}
\hline \multirow{2}{*}{$\begin{array}{c}\text { Galat Taksiran } \\
\text { Regresi }\end{array}$} & \multirow{2}{*}{$\mathrm{N}$} & Lhitung & \multicolumn{2}{c}{$\mathrm{L}_{\text {tabel }}$} & \multirow{2}{*}{ Keterangan } \\
\cline { 4 - 5 } & & & $\alpha=5 \%$ & $\alpha=1 \%$ & \\
\hline $\mathrm{X}_{3}$ atas $\mathrm{X}_{1}$ & 91 & 0,0770 & 0,093 & 0,106 & Normal
\end{tabular}




$\begin{array}{llllll}\mathrm{X}_{3} \text { atas } \mathrm{X}_{2} & 91 & 0,0832 & 0,093 & 0,106 & \text { Normal } \\ \mathrm{X}_{2} \text { atas } \mathrm{X}_{1} & 91 & 0,0880 & 0,093 & 0,106 & \text { Normal }\end{array}$

Berdasarkan hasil pengujian uji normlitas Lhitung dan Ltabel di atas dapat disimpulkan bahwa data dari setiap variabel memiliki nilai yang normal.

\section{Uji Signifikansi dan Linieritas}

1. Uji Signifikansi dan Linieritas Persamaan Regresi OCB atas Kepribadian, dapat dilihat pada tabel 8

Tabel 8 ANAVA Untuk Uji Signifikansi dan Linieritas Persamaan Regresi $\hat{\mathbf{X}}_{3}=62,34+0,43 \mathrm{X}_{1}$

\begin{tabular}{|c|c|c|c|c|c|c|}
\hline \multirow{2}{*}{$\begin{array}{l}\text { Sumber } \\
\text { Varians }\end{array}$} & \multirow{2}{*}{$\mathrm{dk}$} & \multirow{2}{*}{$\begin{array}{c}\text { Jumlah } \\
\text { Kuadrat (JK) }\end{array}$} & \multirow{2}{*}{$\begin{array}{l}\text { Rata-rata Jumlah } \\
\text { Kuadrat (RJK) }\end{array}$} & \multirow{2}{*}{$F_{\text {hitung }}$} & \multicolumn{2}{|c|}{$\mathrm{F}_{\text {tabel }}$} \\
\hline & & & & & $\alpha=0,05$ & $\alpha=0,01$ \\
\hline Total & 91 & 1158812 & & & & \\
\hline Regresi a & 1 & 1150931,38 & & & & \\
\hline Regresi b/a & 1 & 1130,31 & 1130,31 & $14,90^{* *}$ & 3,95 & 6,93 \\
\hline Residu & 89 & 6750,31 & 75,85 & & & \\
\hline Tuna Cocok & 32 & 3093,51 & 96,67 & $1,51 \mathrm{~ns}$ & 1,65 & 2,02 \\
\hline Galat & 57 & 3656,80 & 64,15 & & & \\
\hline
\end{tabular}

Persamaan regresi $\hat{X}_{3}=62,34+0,43 X_{1}$, untuk uji signifikansi diperoleh $F_{\text {hitung }}=$ 14,90 lebih besar dari pada $F_{\text {tabel }} 6,93$ pada $\alpha$ $=0,01$. Karena $F_{\text {hitung }}>F_{\text {tabel }}$ maka persamaan regresi dinyatakan sangat signifikan. Adapun untuk uji linieritas

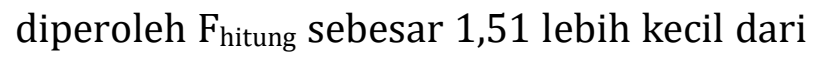
pada $F_{\text {tabel }}=1,65$ pada $\alpha=0,05$. Karena
$F_{\text {hitung }}<F_{\text {tabel }}$ maka sebaran titik yang terestimasi membentuk garis linier dapat diterima.

2. Uji Signifikansi dan Linieritas Persamaan Regresi OCB atas Keadilan Organisasi, dapat dilihat pada tabel 9

Tabel 9 ANAVA Untuk Uji Signifikansi dan Linieritas Persamaan Regresi $\hat{\mathbf{X}}_{3}=76,02+0,30 \mathrm{X}_{2}$

\begin{tabular}{lrrrrrr}
\hline Sumber Varians & $\mathrm{dk}$ & $\begin{array}{c}\text { Jumlah } \\
\text { Kuadrat (JK) }\end{array}$ & $\begin{array}{c}\text { Rata-rata Jumlah } \\
\text { Kuadrat (RJK) }\end{array}$ & $\mathrm{F}_{\text {hitung }}$ & \multicolumn{2}{c}{$\mathrm{F}_{\text {tabel }}$} \\
\cline { 6 - 7 } Total & 91 & 1158812 & & & & \\
Regresi a & 1 & 1150931,38 & & & & \\
Regresi b/a & 1 & 955,76 & 955,76 & $12,28 * *$ & 3,95 & 6,93 \\
Residu & 89 & 6924,86 & 77,81 & & & \\
Tuna Cocok & 25 & 2694,12 & 107,76 & $1,63 \mathrm{~ns}$ & 1,68 & 2,08 \\
Galat & 64 & 4230,74 & 66,11 & & & \\
\hline
\end{tabular}

Persamaan regresi $\hat{X}_{3}=76,02+0,30 X_{2}$, untuk uji signifikansi diperoleh $\mathrm{F}_{\text {hitung }}=$ 12,28 lebih besar dari pada $F_{\text {tabel }} 6,93$ pada $\alpha$
$=0,01$. Karena $F_{\text {hitung }}>F_{\text {tabel }}$ maka persamaan regresi dinyatakan sangat signifikan. Adapun untuk uji linieritas 


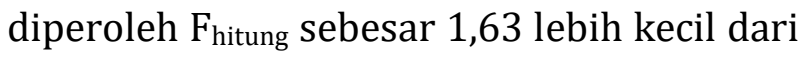
pada $F_{\text {tabel }}=1,68$ pada $\alpha=0,05$. Karena $\mathrm{F}_{\text {hitung }}<\mathrm{F}_{\text {tabel }}$ maka sebaran titik yang terestimasi membentuk garis linier dapat diterima.
3. Uji Signifikansi dan Linieritas Persamaan Regresi Keadilan Organisasi atas Kepribadian, dapat dilihat pada tabel 10

Tabel 10 ANAVA Untuk Uji Signifikansi dan Linieritas Persamaan Regresi $\hat{\mathbf{X}}_{2}=68,68+$ $0,46 X_{1}$

\begin{tabular}{lrrrrrr}
\hline \multicolumn{1}{c}{$\begin{array}{c}\text { Sumber } \\
\text { Varians }\end{array}$} & $\mathrm{dk}$ & $\begin{array}{c}\text { Jumlah } \\
\text { Kuadrat (JK) }\end{array}$ & $\begin{array}{c}\text { Rata-rata Jumlah } \\
\text { Kuadrat (RJK) }\end{array}$ & $\mathrm{F}_{\text {hitung }}$ & \multicolumn{2}{c}{$\mathrm{F}_{\text {tabel }}$} \\
\cline { 6 - 7 } Total & 91 & 1374516 & & & & \\
Regresi a & 1 & 1363731,87 & & & & \\
Regresi b/a & 1 & 1299,31 & 1299,31 & $12,19 * *$ & 3,95 & 6,93 \\
Residu & 89 & 9484,82 & 106,57 & & & \\
Tuna Cocok & 32 & 2718,57 & 84,96 & $0,72 \mathrm{~ns}$ & 1,65 & 2,02 \\
Galat & 57 & 6766,25 & 118,71 & & & \\
\hline
\end{tabular}

Persamaan regresi $\hat{X}_{2}=68,68+0,46 X_{1}$, untuk uji signifikansi diperoleh $\mathrm{F}_{\text {hitung }}=$ 12,19 lebih besar dari pada $F_{\text {tabel }} 6,93$ pada $\alpha$ $=0,01$. Karena $F_{\text {hitung }}>F_{\text {tabel }}$ maka persamaan regresi dinyatakan sangat signifikan. Adapun untuk uji linieritas diperoleh $F_{\text {hitung }}$ sebesar 0,72 lebih kecil dari pada $F_{\text {tabel }}=1,65$ pada $\alpha=0,05$. Karena $F_{\text {hitung }}<F_{\text {tabel }}$ maka sebaran titik yang terestimasi membentuk garis linier dapat diterima.

\section{Pengujian Model}

Hasil analisis jalur model struktur dapat dilihat pada gambar 2:

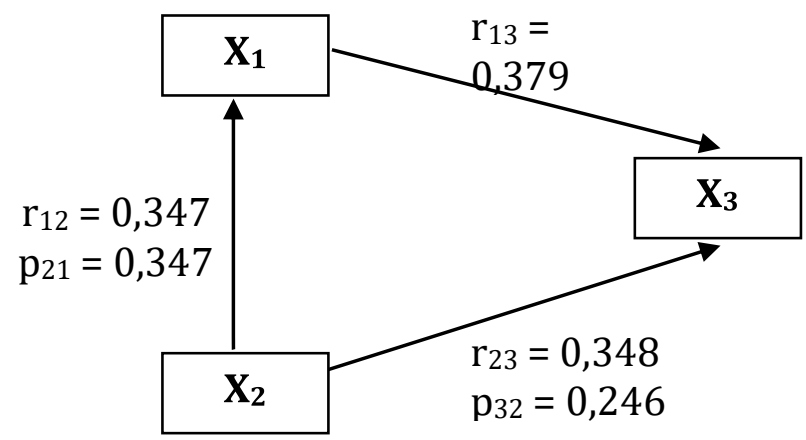

Gambar 2 Model hubungan struktural antar variabel
Berdasarkan hasil perhitungan analisis jalur bahwa dapat dijelaskan sebagai berikut :

1. Nilai koefisien jalur kepribadian terhadap OCB sebesar 0,294 dengan nilai koefisien $t_{\text {hitung }}$ sebesar 2,882. Dengan demikian ada pengaruh langsung variabel kepribadian terhadap OCB yang dinyatakan sangat signifikan. Hasil ini menjelaskan bahwa kepribadian berpengaruh secara langsung positif terhadap OCB. Dengan demikian dapat disimpulkan bahwa OCB dipengaruhi secara langsung positif oleh kepribadian. Meningkatnya kepribadian akan mengakibatkan peningkatan OCB.

2. Nilai koefisien jalur keadilan organisasi terhadap OCB sebesar 0,246 dengan nilai koefisien $t_{\text {hitung }}$ sebesar 2,416. Dengan demikian ada pegaruh langsung variabel keadilan organisasi terhadap OCB yang dinyatakan signifikan. Hasil ini menjelaskan bahwa keadilan organisasi berpengaruh secara langsung positif terhadap OCB. Dengan demikian dapat disimpulkan bahwa OCB dipengaruhi 
secara langsung positif oleh keadilan organisasi. Meningkatnya keadilan organisasi akan mengakibatkan peningkatan OCB.

3. Nilai koefisien jalur kepribadian terhadap keadilan organisasi sebesar 0,347 dengan nilai koefisien thitung sebesar 3,407. Dengan demikian ada pengaruh langsung variabel kepribadian terhadap keadilan organisasi yang dinyatakan sangat signifikan. Hasil ini menjelaskan bahwa kepribadian berpengaruh secara langsung positif terhadap keadilan organisasi. Dengan demikian dapat disimpulkan bahwa keadilan organisasi dipengaruhi secara langsung positif oleh kepribadian. Meningkatnya kepribadian akan mengakibatkan peningkatan keadilan organisasi.

\section{Pengujian Hipotesis}

Hasil yang diperoleh setelah melakukan analisis model digunakan sebagai dasar dalam menjawab hipotesis dan menarik kesimpulan pada penelitian ini. Penjelasan terhadap jawaban hipotesis tersebut sesuai dengan tabel 11

Tabel 11 Hasil pengujian hipotesis yang diajukan

\begin{tabular}{|c|c|c|c|}
\hline Hipotesis & Uji Statistik & Berprestasi & Kesimpulan \\
\hline $\begin{array}{lr}\text { Kepribadian } & \text { berpengaruh } \\
\text { langsung positif } & \text { terhadap } \\
\text { organizational } & \text { citizenship } \\
\text { behavior (OCB) } & \end{array}$ & $\begin{array}{l}\mathrm{H}_{0}: \beta_{31} \leq 0 \\
\mathrm{H}_{1}: \beta_{31}>0\end{array}$ & $\mathrm{H}_{\mathrm{o}}$ ditolak & $\begin{array}{l}\text { berpengaruh } \\
\text { langsung } \\
\text { positif }\end{array}$ \\
\hline $\begin{array}{lr}\text { Keadilan organisasi } & \text { berpengaruh } \\
\text { langsung positif } & \text { terhadap } \\
\text { organizational } & \text { citizenship } \\
\text { behavior (OCB) } & \end{array}$ & $\begin{array}{l}\mathrm{H}_{\mathrm{o}}: \beta_{32} \leq 0 \\
\mathrm{H}_{1}: \beta_{32}>0\end{array}$ & $\mathrm{H}_{\mathrm{o}}$ ditolak & $\begin{array}{l}\text { berpengaruh } \\
\text { langsung } \\
\text { positif }\end{array}$ \\
\hline $\begin{array}{l}\text { Kepribadian } \quad \text { berpengaruh } \\
\text { langsung positif terhadap keadilan } \\
\text { organisasi }\end{array}$ & $\begin{array}{l}\mathrm{H}_{\mathrm{o}}: \beta_{21} \leq 0 \\
\mathrm{H}_{1}: \beta_{21}>0\end{array}$ & $\mathrm{H}_{\mathrm{o}}$ ditolak & $\begin{array}{l}\text { berpengaruh } \\
\text { langsung } \\
\text { positif }\end{array}$ \\
\hline
\end{tabular}

\section{Hipotesis Pertama}

Kepribadian berpengaruh langsung positif terhadap Organizational Citizenship Behavior (OCB).

Ho : $\beta_{31} \leq 0$

$\mathrm{H}_{1}: \beta_{31}>0$

Ho ditolak, jika $t_{\text {hitung }}>t_{\text {tabel }}$

Dari hasil analisis jalur yang menjelaskan hipotesis pertama pada penilitian ini yaitu pengaruh kepribadian terhadap OCB mempunyai nilai koefisien jalur yaitu 0,294. Adapun nilai thitung 2,882 sedangkan $t_{\text {tabel }}$ sebesar 2,63. Dari data nilai yang telah dijelaskan pada hipotesis pertama bahwa nilai $t_{\text {hitung }}>t_{\text {tabel }}$ maka dapat diambil keputusan bahwa Ho ditolak dan H1 diterima yang menjelaskan bahwa adanya pengaruh antara kepribadian terhadap OCB. Dengan demikian dapat disimpulkan bahwa OCB dipengaruhi secara langsung positif oleh kepribadian. Meningkatnya kepribadian akan mengakibatkan peningkatan OCB.

2. Hipotesis Kedua

Keadilan organisasi berpengaruh langsung positif terhadap Organizational Citizenship Behavior (OCB).

Ho : $\beta_{32} \leq 0$ 
$\mathrm{H}_{1}: \beta_{32}>0$

Ho ditolak , jika $t_{\text {hitung }}>t_{\text {tabel }}$

Dari hasil analisis jalur yang menjelaskan hipotesis kedua pada penelitian ini yaitu pengaruh keadilan organisasi terhadap OCB mempunyai nilai koefisien jalur sebesar 0,246. Adapun nilai thitung 2,416 sedangkan $t_{\text {tabel }}$ 1,99. Dari data nilai yang telah dijelaskan pada hipotesis kedua bahwa nilai $t_{\text {hitung }}>t_{\text {tabel }}$ maka dapat diambil keputusan bahwa Ho ditolak dan $\mathrm{H}_{1}$ diterima yang menjelaskan bahwa adanya pengaruh antara keadilan organisasi terhadap OCB. Dengan demikian dapat disimpulkan bahwa OCB dipengaruhi secara langsung positif oleh keadilan organisasi. Meningkatnya keadilan organisasi akan mengakibatkan peningkatan OCB.

\section{Hipotesis Ketiga}

Kepribadian berpengaruh langsung positif terhadap keadilan organisasi.

Ho : $\beta_{21} \leq 0$

$\mathrm{Hi}: \beta_{21}>0$

Ho ditolak, jika $t_{\text {hitung }}>t_{\text {tabel }}$

Dari hasil analisis jalur yang menjelaskan hipotesis ketiga pada penelitian ini yaitu pengaruh kepribadian terhadap keadilan organisasi mempunyai nilai koefisien jalur sebesar 0,347. Adpun nilai thitung 3,407 sedangkan nilai tabel 2,63. Dari data nilai yang dijelaskan hipotesis ketiga bahwa $t_{\text {hitung }}>t_{\text {tabel }}$ maka dapat diambil keputusan bahwa Ho ditolak dan $\mathrm{H}_{1}$ diterima yang menejelaskan bahwa adanya pengaruh antara kepribadian terhadap keadilan organisasi dapat diterima. Dengan demikian dapat disimpulkan bahwa keadilan organisasi dipengaruhi secara langsung positif oleh kepribadian. Meningkatnya kepribadian akan mengakibatkan peningkatan keadilan organisasi.

\section{Pembahasan}

Berdasarkan tinjauan pustaka yang telah dibahas dan kajian empiris di atas, selanjutnya peneliti akan membahas hasil penelitian sebagai upaya untuk melakukan sintesis antara kajian teori dengan temuan empiris. Pembahasan pertama adalah peneliti menjelaskan pengaruh kepribadian terhadap OCB. Dari hasil pengujian hipotesis dapat disimpulkan bahwa terdapat pengaruh langsung positif kepribadian terhadap OCB dengan nilai koefisien jalur sebesar 0,294 dan nilai koefisien korelasi sebesar 0,379. Hasil penelitian ini sesuai dengan teori (Glinow, 2008), bahwa lima dimensi kepribadian tersebut mempengaruhi perilaku kerja dan prestasi kerja untuk berbagai tingkatan. Karyawan yang memiliki kesadaran tinggi memiliki tingkat kewargaan organisasi yang lebih tinggi dan bekerja lebih baik di tempat kerja yang memberikan kebebasan lebih dalam keputusan dan pengawasan di tempat kerja. Kemudian hasil ini juga sesuai dengan teori Colquit (2011:316), bahwa kesadaran memiliki pengaruh positif pada kinerja. Karyawan yang memiliki kesadaran tingkat tinggi akan mempunyai kinerja tugas yang baik. Mereka juga terlibat untuk memunculkan perilaku kewargaan dan kecil kemungkinannya untuk terlibat dalam perilaku kontraproduktif.

Pembahasan hasil yang selanjutnya menjelaskan pengaruh keadilan organisasi terhadap OCB memberikan penjelasan bahwa terdapat pengaruh langsung positif keadilan organisasi terhadap OCB dengan nilai koefisien jalur sebesar 0,246 dan nilai koefisien korelasi sebesar 0,348. Hasil ini sesuai dengan teori (R.Jones, 2012), yang menjelaskan bahwa keadilan organisasi berpengaruh secara positif terhadap kepuasan kerja, komitmen organisasi, prestasi kerja, dan perilaku kewargaan 
organisasi dan negatif terkait dengan tingkat ketidakhadiran dan turnover. Selanjutnya (Gibson, 2009) juga menjelaskan bahwa, teori keadilan telah menunjukkan adanya pengaruh terhadap kedua kewargaan organisasi dan sikap terhadap membangun tugas dan kelompok kerja.

Pembahasan hasil selanjutnya adalah pengaruh kepribadian terhadap eadilan organisasi. Dari hasil pengujian hipotesis dapat disimpulkan bahwa terdapat pengaruh langsung positif kepribadian terhadap keadilan organisasi dengan nilai koefisien jalur sebesar 0,347 dan nilai koefisien korelasi sebesar 0,347. Hasil ini sesuai dengan teori Colquit (2011: 294), yang menjelaskan bahwa melalui tiga teori integratif yang bersumber dari model circumplex kepribadian dapat menunjukkan pengaruh antara kepribadian terhadap keadilan.

\section{KESIMPULAN DAN IMPLIKASI}

\section{Kesimpulan}

Berdasarkan hasil penelitian yang telah dilakukan, maka dapat disimpulkan bahwa: (1) terdapat pengaruh langsung positif kepribadian terhadap organizational citizenship behavior. Artinya ketika kepribadian semakin baik, maka organizational citizenship behavior juga akan meningkat, (2) terdapat pengaruh langsung positif keadilan organisasi terhadap organizational citizenship behavior, artinya jika keadilan organisasi semakin meningkat, maka organizational citizenship behavior juga akan meningkat, (3) terdapat pengaruh langsung positif kepribadian terhadap keadilan organisasi. Hal ini menunjukkan bahwa jika tingkat kepribadian yang dilakukan semakin baik, maka tingkat keadilan organisasi juga akan semakin baik.

\section{Implikasi}

Berdasarkan kesimpulan hasil penelitian ini dengan memperhatikan fakta-fakta di lapangan dapat dikemukakan bahwa terdapat pengaruh antara kepribadian dan keadilan organisasi terhadap organizational citizenship behavior guru. Dengan kata lain bahwa organizational citizenship behavior dapat ditentukan oleh kepribadian dan keadilan organisasi. Maka implikasi hasil penelitian ini akan diarahkan kepada upaya peningkatan organizational citizenship behavior melalui variabel kepribadian dan keadilan organisasi.

Hasil penelitian yang menunjukkan bahwa kepribadian memberikan pengaruh positif terhadap organizational citizenship behavior guru. Dengan demikian, perilaku organizational citizenship behavior guru dapat ditingkatkan dengan meningkatkan kepribadian guru. Terciptanya organizational citizenship behavior guru dapat membantu sekolah dalam mencapai tujuan yang diharapkan. Adapun pihak sekolah dalam hal ini kepala sekolah berupaya memperhatikan kepribadian guru berupa ekstraversi atau kemampuan bersahabat, keramahtamahan, kesadaran, stabilitas emosional dan keterbukaan terhadap pengalaman memlalui bimbingan motivasi dan seminar-seminar pengembangan diri.

Hasil penelitian yang memberi penjelasan bahwa keadilan organisasi memberikan pengaruh positif terhadap organizational citizenship behavior guru. Dengan demikian, perilaku organizational citizenship behavior guru akan meningkat dengan meningkatkan keadilan organisasi. Adapun usaha yang dapat dilakukan oleh pihak sekolah adalah berupaya untuk 
memberikan gaji guru sesuai dengan beban kerja dan kompetensinya, memberikan kesempatan yang sama menerima penghargaan, memberikan proses pengambilan keputusan dengan standar yang jelas dan menciptakan interaksi guru dan kepala sekolah dengan penuh sopan santun, kejujuran, martabat dan hormat kepada sesama.

Hasil penelitian yang memberi penjelasan bahwa kepribadian memberikan pengaruh positif terhadap keadilan organisasi. Dengan demikian, keadilan organisasi guru akan meningkat dengan meningkatkan kepribadian guru. Adapun Sekolah dapat melakukan kegiatan bagi guru dengan memberikan kesempatan yang sama kepada guru untuk mengikuti bimbingan motivasi, meyakinkan guru bahwa sekolah bersikap terbuka atas informasi-informasi dari dinas terkait. memberikan kesempatan kepada semua guru untuk mengikuti seminar pengembangan diri.

\section{DAFTAR PUSTAKA}

Nugroho, H. T. (2009). Kebijakan Pendidikan,Pengantar Untuk Memahami Kebijakan Pendidikan Sebagai Kebijakan Publik. Yogyakarta: Pustaka Belajar.

Jason A. Colquit, J. A. (2011). Organizational Behavior, Second Edition. Newyork: McGraw Hill.

R.Jones, J. M. (2012). Understanding and Managing Organizational Behavior, Sixt Edition. New Jersey: Pearson Education.

Gibson, I. D. (2009). Organizations Behavior,Structure,Processes. New York: McGraw Hill Companies.

Glinow, M. a. (2008). Organizational Behavior, Emerging Knowledge and Practice For the Real World. New York: McGraw Hill.

Stephen P. Robbins, T. A. (2007). Organizational Behavior. New Jersey: Prentice Hall.

M.Ryckman, R. (2008). Theories of Personality. USA: Thomson Higher Education.

Schermerhorn., J. R. (2012). Organizational Behavior. Hoboken: John Wiley and Sons Inc. 